\title{
Quantifying ruminal digestion of organic matter and neutral detergent fiber using the omasal sampling technique in cattle-A meta-analysis ${ }^{1}$
}

\author{
P. Huhtanen, ${ }^{* 2}$ S. Ahvenjärvi, $†$ G. A. Broderick, $\ddagger$ S. M. Reynal,$\ddagger^{3}$ and K. J. Shingfield $\dagger$ \\ ${ }^{*}$ Department of Animal Science, Swedish University of Agricultural Sciences, Umeå, S-90183 Sweden \\ †Animal Production Research, MTT Agrifood Research Finland, Jokioinen, FI-31600 Finland \\ $\ddagger$ Agricultural Research Service, USDA US Dairy Forage Research Center, 1925 Linden Drive West, Madison, WI 53706
}

\section{ABSTRACT}

A data set from 32 studies (122 diets) was used to evaluate the accuracy and precision of the omasal sampling technique by investigating the relationships between ruminal and total digestion of neutral detergent fiber (NDF), between intake and apparent and true ruminal digestion of organic matter (OM), and between omasal NAN flow and milk protein yield. A mixed model regression analysis with random study effect was used to evaluate the relationships. The data were obtained when feeding North American diets $(\mathrm{n}=36)$ based on alfalfa silage, corn silage, and corn grain and North European diets $(\mathrm{n}=86)$ comprising grass silage supplemented with barley-based concentrates. In all studies, digesta flow was quantified using a triple-marker approach. Standard deviations of ruminal NDF and true OM digestibility were smaller than typically reported in duodenal sampling studies using only chromic oxide as a flow marker. The relationship between total and ruminal NDF digestion was consistent, indicating little variation in the proportion of total-tract NDF digestion that occurred in the rumen. Furthermore, the slope of this regression indicated that $94.7 \%( \pm 2.7 \%)$ of total NDF digestion occurred in the rumen. The slopes of mixed model regression equations between $\mathrm{OM}$ intake and amount digested indicated that $42 \%( \pm 2.4 \%)$ and $74 \%( \pm 3.1 \%)$ of OM was apparently and truly digested in the rumen, respectively. The contribution of the rumen to total-tract apparent OM digestion was $62 \%$ $( \pm 2.6 \%)$. The close relationship between omasal flow of nonammonia crude protein and milk protein yield (with adjusted residual mean squared error $=31 \mathrm{~g}$ ) provided further confidence in the reliability of omasal flow measurements.

\footnotetext{
Received December 11, 2009.

Accepted March 19, 2010.

${ }^{1}$ Mention of any trademark or proprietary product in this paper does not constitute a guarantee or warranty of the product by the USDA or the Agricultural Research Service and does not imply its approval to the exclusion of other products that also may be suitable.

${ }^{2}$ Corresponding author: pekka.huhtanen@njv.slu.se

${ }^{3}$ Deceased June 25, 2007.
}

Key words: meta-analysis, omasal sampling, ruminal digestion

\section{INTRODUCTION}

Current feed protein evaluation systems for ruminants (e.g., NRC, 2001) are dependent upon measurements of microbial protein formation in the rumen. Traditionally, measurement of compartmental nutrient flows within the digestive tract and microbial protein synthesis in the rumen have relied on sampling through simple T-cannulas fitted in the abomasum or proximal duodenum (Harmon and Richards, 1997; Titgemeyer, 1997). Obtaining unrepresentative samples that may be contaminated with endogenous secretions into the abomasum are among the problems associated with this approach (Harmon and Richards, 1997; Huhtanen et al., 1997). In addition, duodenally cannulated animals require special care and may have shortened life spans. Attempts have been made using various types of omasal cannulas (Harmon and Richards, 1997; Huhtanen et al., 1997), but many of these methods require surgery that is even more invasive than that needed for duodenal sampling and therefore have not been widely adopted.

Flow estimates from duodenal sampling have been variable (Titgemeyer, 1997) and, therefore, researchers have sought other approaches for quantifying digestive processes in the rumen. Hristov and Broderick (1996) proposed a ruminal sampling method based on rumen evacuation and digesta passage kinetics, and later Hristov (2007) introduced a reticular sampling technique. Punia et al. (1988) sampled omasal digesta by inserting a tube through the reticulo-omasal orifice via the ruminal cannula and withdrawing digesta using a vacuum pump. However, this procedure required insertion of the sampling tube at each sampling time. Huhtanen et al. (1997) developed an omasal sampling technique allowing digesta sampling from the omasal canal via a ruminal cannula without repeated entry into the omasum. The sampling system consisted of a device inserted into the omasum via the ruminal cannula, a tube connecting the device to the ruminal cannula, and a single compressor/vacuum pump for withdrawing samples 
through this tube. This technique was further modified by Ahvenjärvi et al. (2000) and has subsequently been applied in several studies. Omasal sampling conducted in this way requires less surgical intervention than using abomasal or duodenal cannulas as the sampling sites for studying reticulo-rumen digestion; moreover, it avoids potentially confounding contamination from abomasal secretions. In a direct comparison of methods, OM flow into the duodenum was significantly greater than that into the omasum, indicating quantitatively important endogenous secretions into the abomasum (Ahvenjärvi et al., 2000). In contrast, NDF flow into the duodenum was lower, indicating that additional cell wall digestion occurred between the omasum and duodenum. Results from another study with corn-based diets were less conclusive (Ipharraguerre et al., 2007). However, these latter estimates of ruminal $\mathrm{OM}$ and starch digestibility obtained using duodenal sampling were unrealistically low and even negative using some markers.

Validity of omasal sampling data can also be evaluated by determining whether data fall within biological limits (Titgemeyer, 1997). Partitioning NDF digestion between ruminal and postruminal compartments is a good criterion because retention time in postruminal fermentation compartments is relatively short compared with that in the rumen (Ellis et al., 2002; Huhtanen et al., 2006) and NDF entering the hindgut is less digestible than ingested NDF. Unrealistically high or even negative proportions of hind-gut digestion of total NDF digestion imply unrepresentative digesta sampling or marker dysfunction, as will be discussed later. Partitioning of $\mathrm{OM}$ digestion can also be used to assess the accuracy of flow measurements, but the contributions of postruminal segments are more important for digestion of nonfiber components such as starch, fat, and protein escaping the rumen. Milk protein secretion in dairy cows is closely associated with the supply of metabolizable protein (NRC, 2001); thus, variation in milk protein yield among the treatments should be sensitive to differences in omasal NAN flow. For flow studies comparing diets within a study, precision (residual standard deviation) is more important than accuracy in comparing different treatments; however, accuracy in describing the effects of diets and feedstuffs on nutrient flows is most important for feed evaluation systems (St-Pierre, 2001).

The objective of this paper is to evaluate the omasal sampling technique for quantifying reticulo-rumen digestion by partitioning of NDF and OM digestion between gastrointestinal compartments and by assessing the relationship between NAN flows at the omasum and milk protein yield. In a companion paper (Broderick et al., 2010), a meta-analysis of omasal sampling data on ruminal $\mathrm{N}$ metabolism is presented.

\section{MATERIALS AND METHODS}

\section{Data}

Observations were collected from 32 studies in which nutrient flow at the omasum was determined for 122 dietary treatments. Twenty-two of these studies were conducted in Northern Europe: 3 trials (10 diets) were conducted by 1 research group with growing cattle and 19 trials (76 diets) were conducted with lactating dairy cows by 2 other research groups. Ten studies (36 diets) were conducted in North America by 2 additional research groups using only lactating dairy cows. Individual studies used to compile this dataset are listed in the Appendix. All of these studies were conducted as single or duplicated Latin squares. The mean number of observations per treatment was 5.3 (range 4-10). Three studies (10 diets) were conducted with growing cattle and the rest with lactating dairy cows. In all studies, digesta flow to the omasum was determined using a triple-marker approach (France and Siddons, 1986). The digesta markers were the internal marker indigestible NDF (iNDF; $\mathrm{n}=100$ ) or $\mathrm{Cr}$ mordanted fiber $(n=22)$ for the large particle phase, $\mathrm{Yb}$-chloride or $\mathrm{Yb}$-acetate for the small particle phase, and CoEDTA as the liquid phase marker. When used, Cr-mordanted fiber was administered twice daily into the rumen, whereas Yb-chloride/acetate and CoEDTA were continuously infused into the rumen in all trials. Chromium-mordanted fiber and CoEDTA were prepared as described by Udén et al. (1980). Indigestible NDF was determined as the residual NDF remaining after 12-d in situ incubation in the rumen using nylon bags of small pore size (Huhtanen et al., 1994) and expressed on an ash-free basis. Details of marker administrations are described in Ahvenjärvi et al. (2000) and Reynal and Broderick (2003). The animals were fed once daily or twice daily at 12 -h intervals $(50 \%$ of daily ration at each meal). From 8 to 12 spot samples of omasal digesta were collected over 3- or 4-d collection periods so that the sampling times were equally distributed over the 12 or 24-h feeding cycle. Microbial protein synthesis was determined for 96 diets (25 studies) using either purine bases $(\mathrm{n}=22)$ or ${ }^{15} \mathrm{~N}(\mathrm{n}=74)$ as microbial markers. In the North American studies, the values of OM truly digested in the rumen (OMTDR) were not corrected for VFA (the end products of digestion) flow to the omasum. Thus, these OMTDR values are underestimates of true OM digestion in the rumen because VFA are not lost during drying at omasal digesta $\mathrm{pH}$ (mean 6.5) but evaporate at duodenal digesta $\mathrm{pH}$ (Ahvenjärvi et al., 2000). Therefore, reported OMTDR values were corrected for VFA flow using the relationship between DMI and VFA flow derived from other studies in the 
data set. The following mixed model equation was used to estimate VFA flow for North American data: VFA flow $(\mathrm{g} / \mathrm{d})=-53( \pm 340)+77.1( \pm 4.8) \times \mathrm{OM}$ intake $(\mathrm{kg} / \mathrm{d})+11.0( \pm 1.3) \times[($ rumen VFA -103$)$, $(\mathrm{mmol} / \mathrm{L})]+557( \pm 71.2) \times($ rumen $\mathrm{pH}-6.49) ;[\mathrm{n}=$ 60; residual mean square error (RMSE) adjusted for random study effect $=87$. The mean $(\mathrm{SD})$ OM intake, rumen VFA concentration, and $\mathrm{pH}$ was 15.1 (3.8) kg/d, $103(14.2) \mathrm{mmol} / \mathrm{L}$, and $6.49(0.19)$, respectively. The measured mean omasal VFA flow for these diets was $1.19(0.31) \mathrm{kg} / \mathrm{d}$. The calculated VFA correction for the North American data was $1.60(0.30) \mathrm{kg} / \mathrm{d}$.

Total-tract digestibility was determined by total fecal collection $(\mathrm{n}=88)$ or by using internal markers (acid-insoluble ash, indigestible ADF; $\mathrm{n}=34$ ). Rumen fermentation pattern ( $\mathrm{pH}$ and VFA) was measured in all studies based on sampling covering the whole feeding cycle (12 or $24 \mathrm{~h})$.

\section{Diets}

The diets were typical of those fed to North American $(\mathrm{n}=36)$ or North European $(\mathrm{n}=86)$ dairy and beef cattle. The former were mainly based on corn silage, alfalfa silage, corn grain, and soybean meal, and the latter mainly on grass silage, barley, oats, rapeseed, and soybean meal. The animals were fed TMR in 11 studies (46 diets), whereas forages and concentrates were fed separately in 21 studies (76 diets). All diets were analyzed for OM, CP, and NDF concentrations. Fat (determined as ether extract) and starch concentrations of the concentrates were either measured or computed from tabulated values for each separate ingredient (NRC, 2001; MTT, 2006). Nonfiber carbohydrate concentration was calculated as $\mathrm{OM}-\mathrm{CP}-(\mathrm{NDF}-\mathrm{ND}-$ FCP) - fat. In Northern European studies, NDF was analyzed using amylase and expressed as ash-free, but not corrected for NDFCP. Specific details of chemical analyses are described in the original publications (see Appendix).

\section{Calculations}

Apparent and true digestion of $\mathrm{OM}$ in the rumen was calculated as follows:

$$
\begin{gathered}
\text { OM apparently digested }=\mathrm{OM} \text { intake } \\
- \text { omasal OM flow; }
\end{gathered}
$$

OM truly digested $=\mathrm{OM}$ intake - (omasal OM flow - omasal microbial OM flow - omasal VFA flow),

where $\mathrm{OM}$ digested, intake, and flow are in kilograms per day.
Intake of digestible OM at maintenance level of intake was calculated as described by Nousiainen et al. (2009). Briefly, OM digestibility at maintenance intake $\left(\mathbf{O M D}_{\mathrm{M}}\right)$ for concentrates was estimated using analyzed chemical composition and tabulated digestibility coefficients (MTT, 2006). For forages, $\mathrm{OMD}_{\mathrm{M}}$ was determined in vivo in sheep fed at maintenance or in vitro using rumen fluid or a pepsin-cellulase method, or was calculated from iNDF concentration as described by Huhtanen et al. (2006) using forage-specific equations (Huhtanen et al., 2006; Rinne et al., 2006). Within a study, the same method was used consistently to estimate forage digestibility.

\section{Statistical Analysis}

Regression analyses were performed using PROC MIXED in SAS (SAS Institute, 1999) with the discrete effect of study included as a random variable (St-Pierre, 2001). The model was $\mathrm{Y}=\mathrm{B}_{0}+\mathrm{B}_{1} \mathrm{X} 1_{\mathrm{ij}}+\mathrm{b}_{0}+\mathrm{b}_{1} \mathrm{X} 1_{\mathrm{ij}}+$ $\mathrm{B}_{2} \mathrm{X} 2_{\mathrm{ij}}+\ldots+\mathrm{B}_{\mathrm{n}} \mathrm{X} n_{\mathrm{ij}}+\mathrm{e}_{\mathrm{ij}}$, where $\mathrm{B}_{0}, \mathrm{~B}_{1} \mathrm{X} 1_{\mathrm{ij}}, \mathrm{B}_{2} \mathrm{X} 2_{\mathrm{ij}} \ldots$ $\mathrm{B}_{\mathrm{n}} \mathrm{Xn}_{\mathrm{ij}}$ are the fixed effects and $\mathrm{b}_{0}, \mathrm{~b}_{1}$, and $\mathrm{e}_{\mathrm{ij}}$ are the random experiment effects (intercept and slope), where $\mathrm{i}=1 \ldots \mathrm{n}$ studies and $\mathrm{j}=1 \ldots \mathrm{n}$ values. The objective of modeling OM and NDF flow data was to estimate digestibility in the rumen or intestines by regressing omasal flows or rumen digestion against intake. The models were first constructed based on a single parameter and then other biologically relevant variables were included. Any additional parameter was assumed to be a fixed factor. The best-fit model was chosen based on the lowest RMSE. Adjusted observations were calculated for the figures by adding the residual from each individual observation to the predicted value of the study regression. For the limited data of starch flow at the omasum (16 diets, 4 studies), ruminal digestibility was estimated using the Lucas principle (see Van Soest, 1994) by regressing digestible starch concentration against starch concentration in diet DM. In the tables, RMSE values are adjusted for the random study effect. Rationale and further details of using mixed model analysis to integrate quantitative findings from multiple studies are described by St-Pierre (2001).

\section{RESULTS}

\section{Data}

Dietary characteristics, omasal flow, digestibility, and animal data are shown in Table 1. Both diet composition and animal data displayed large variations. Results from the studies with beef cattle $(\mathrm{n}=10)$ extended the range in intake data. In addition to the use of different breeds (US Holsteins and Finnish Ayrshire), variation in diet composition (forage alone vs. high-concentrate 
Table 1. Diet and animal characteristics of the data set used to evaluate results from omasal sampling studies

\begin{tabular}{|c|c|c|c|c|c|}
\hline Item & $\mathrm{n}$ & Mean & $\mathrm{SD}$ & Minimum & Maximum \\
\hline \multicolumn{6}{|l|}{ Diet composition (g/kg DM) } \\
\hline $\mathrm{CP}$ & 122 & 158 & 22.6 & 99 & 237 \\
\hline $\mathrm{RDP}^{1}$ & 122 & 113 & 17.3 & 75 & 177 \\
\hline RUP $^{1}$ & 122 & 46 & 12.5 & 23 & 98 \\
\hline $\mathrm{NDF}$ & 122 & 372 & 83.7 & 219 & 595 \\
\hline $\mathrm{NFC}$ & 122 & 363 & 86.3 & 147 & 554 \\
\hline Starch & 122 & 195 & 113.7 & 0 & 422 \\
\hline \multicolumn{6}{|l|}{ Intake $(\mathrm{kg} / \mathrm{d})$} \\
\hline $\mathrm{DM}$ & 122 & 19.1 & 4.42 & 6.03 & 27.4 \\
\hline $\mathrm{OM}$ & 122 & 17.7 & 4.15 & 5.51 & 25.3 \\
\hline $\mathrm{NDF}$ & 122 & 6.87 & 1.51 & 3.41 & 9.8 \\
\hline \multicolumn{6}{|l|}{ Omasal flow $(\mathrm{kg} / \mathrm{d})$} \\
\hline $\mathrm{OM}$ & 122 & 9.42 & 2.57 & 2.59 & 14.5 \\
\hline $\mathrm{NDF}$ & 122 & 3.02 & 0.82 & 0.67 & 4.92 \\
\hline $\mathrm{CP}$ & 122 & 2.95 & 0.90 & 0.54 & 4.79 \\
\hline \multicolumn{6}{|l|}{ Rumen digestion (kg/d) } \\
\hline $\mathrm{OMADR}^{2}$ & 122 & 8.28 & 1.82 & 2.75 & 11.0 \\
\hline $\mathrm{OMTDR}^{2}$ & 96 & 13.2 & 3.29 & 4.57 & 19.0 \\
\hline NDF & 122 & 3.85 & 1.37 & 1.32 & 6.82 \\
\hline \multicolumn{6}{|l|}{ Rumen digestibility (\%) } \\
\hline Apparent OM & 122 & 47.2 & 4.73 & 35.1 & 63.8 \\
\hline True OM & 96 & 67.8 & 4.58 & 54.9 & 80.6 \\
\hline NDF & 122 & 55.1 & 12.50 & 27.0 & 80.9 \\
\hline \multicolumn{6}{|l|}{ Total-tract digestibility (\%) } \\
\hline $\mathrm{OM}$ & 118 & 72.8 & 4.44 & 57.0 & 86.4 \\
\hline $\mathrm{NDF}$ & 118 & 59.4 & 12.0 & 30.5 & 83.6 \\
\hline \multicolumn{6}{|l|}{ Animal data } \\
\hline BW (kg) & 122 & 603 & 45.2 & 436 & 671 \\
\hline Milk yield $(\mathrm{kg} / \mathrm{d})$ & 112 & 28.8 & 6.77 & 14.1 & 42.4 \\
\hline Milk protein yield $(\mathrm{g} / \mathrm{d})$ & 112 & 924 & 196 & 535 & 1,320 \\
\hline
\end{tabular}

${ }^{1} \mathrm{RDP}$ and RUP are estimated according to NRC (2001).

${ }^{2} \mathrm{OMADR}=\mathrm{OM}$ apparently digested in the rumen $(\mathrm{kg} / \mathrm{d}) ; \mathrm{OMTDR}=\mathrm{OM}$ truly digested in the rumen $(\mathrm{kg} / \mathrm{d})$.

and high-CP mixed diets) contributed to the wide range in intake and milk production.

\section{OM and Starch Digestion}

The models describing OM digestion are in Table 2 . These data were analyzed using both mixed and fixed model regressions (simple regression without study effect) to evaluate uniformity of flow estimates between the trials. It should be noted that the $\mathrm{R}^{2}$ value for the mixed model includes study effect and is therefore not a useful indicator of explained variation. The fit of the OM intake model (mixed) was improved when $\mathrm{OMD}_{\mathrm{M}}$ was included as an independent variable in the equation, reflecting the positive effect of intrinsic diet digestibility on the amount of $\mathrm{OM}$ digested at a given DMI:

$$
\begin{aligned}
& \text { OMTDR }(\mathrm{kg} / \mathrm{d})=-7.7( \pm 1.72)+0.73( \pm 0.032) \\
\times & \text { OM intake }(\mathrm{kg} / \mathrm{d})+0.101( \pm 0.022) \times \mathrm{OMD}_{\mathrm{M}}(\%)
\end{aligned}
$$

$$
\text { (Adj. RMSE }=0.27 \text { ). }
$$

Dietary concentrations of carbohydrate fractions (NDF, starch, and NFC) or CP had no significant effect on OMTDR when included as a third parameter to model [1]. However, OMTDR was positively associated with dietary RDP concentration $(P=0.07)$ and ruminal protein degradability $(P=0.01)$ and negatively associated with dietary concentration of RUP $(P=0.04)$ and fat $(P=0.11)$, when these dietary characteristics were estimated according to the NRC (2001) model.

The slope between OM intake and OM apparently digested in the rumen (OMADR) indicated that 41 to $42 \%$ of ingested $\mathrm{OM}$ was apparently digested in the rumen, and the contribution of OMADR to totaltract OM digestion was, on average, $62 \%$. Median SD values of apparent and true OM digestibility in the rumen were $3.4(\mathrm{n}=122)$ and $2.8 \%(\mathrm{n}=86)$, respectively.

Quantities of OM truly digested in the rumen and apparently digested in the total tract were similar (13.0 and $12.9 \mathrm{~kg} / \mathrm{d} ; \mathrm{n}=92$ ). Approximately $50 \%$ of $\mathrm{OM}$ flowing into the omasum was apparently digested in the intestines. The parameter values were similar when 
Table 2. Mixed and fixed regression models describing OM digestion $(\mathrm{kg} / \mathrm{d})^{1}$

\begin{tabular}{|c|c|c|c|c|c|c|c|c|c|c|}
\hline Parameter & Variable & Model $^{2}$ & $\mathrm{n}$ & Intercept & $\mathrm{SE}$ & $P$-value & Estimate $^{3}$ & $\mathrm{SE}$ & $\mathrm{RMSE}^{4}$ & Adjusted $\mathrm{R}^{2}$ \\
\hline OMADR & OMI & $\mathrm{F}$ & 122 & 1.10 & 0.281 & $<0.01$ & 0.41 & 0.015 & 0.71 & 0.85 \\
\hline OMTDR & OMI & $\mathrm{F}$ & 96 & 0.24 & 0.298 & 0.43 & 0.72 & 0.016 & 0.70 & 0.96 \\
\hline OMADR & OMDTT & M & 114 & 0.37 & 0.340 & 0.28 & 0.62 & 0.026 & 0.30 & 0.97 \\
\hline OMTDR & OMDTT & $\mathrm{F}$ & 88 & -0.48 & 0.349 & 0.17 & 1.05 & 0.026 & 0.76 & 0.95 \\
\hline OMDI & OM flow & M & 114 & -0.12 & 0.267 & 0.65 & 0.51 & 0.029 & 0.21 & 0.97 \\
\hline OMDI & OM flow & $\mathrm{F}$ & 114 & 0.39 & 0.169 & 0.02 & 0.45 & 0.018 & 0.47 & 0.85 \\
\hline
\end{tabular}

${ }^{1} \mathrm{OMADR}=\mathrm{OM}$ apparently digested in the rumen $(\mathrm{kg} / \mathrm{d}) ; \mathrm{OMI}=\mathrm{OM}$ intake $(\mathrm{kg} / \mathrm{d}) ;$ OMTDR $=\mathrm{OM}$ truly digested in the rumen $(\mathrm{kg} / \mathrm{d}) ;$ OMDTT $=\mathrm{OM}$ digested in the total tract $(\mathrm{kg} / \mathrm{d}) ; \mathrm{OMDI}=\mathrm{OM}$ digested in the intestines $(\mathrm{kg} / \mathrm{d}) ;$ OM flow $=$ OM flow into the omasum $(\mathrm{kg} / \mathrm{d})$.

${ }^{2} \mathrm{M}=$ mixed model; $\mathrm{F}$ = fixed model (simple regression without study effect).

${ }^{3}$ All estimates statistically significant, $P<0.001$.

${ }^{4}$ Residual mean square error; values with mixed model analysis are adjusted for random study effect.

the data were analyzed with mixed or fixed regression models, but adjusted RMSE was smaller with mixed model analyses than RMSE with fixed model analyses.

According to the Lucas test, starch behaved as a uniform nutritional entity (Figure 1). The slope of the regression representing true ruminal starch digestibility was $0.85(\mathrm{SE}=0.03)$. Intercept $(10.7 ; \mathrm{SE}=6.0)$ is an estimate of microbial starch flow in grams per kilogram of DMI. Using mixed model analysis, the regression parameters remained similar $(0.85,10.4)$ but RMSE adjusted for random study effect decreased from 9.0 to $5.6 \mathrm{~g} / \mathrm{kg}$ of DMI.

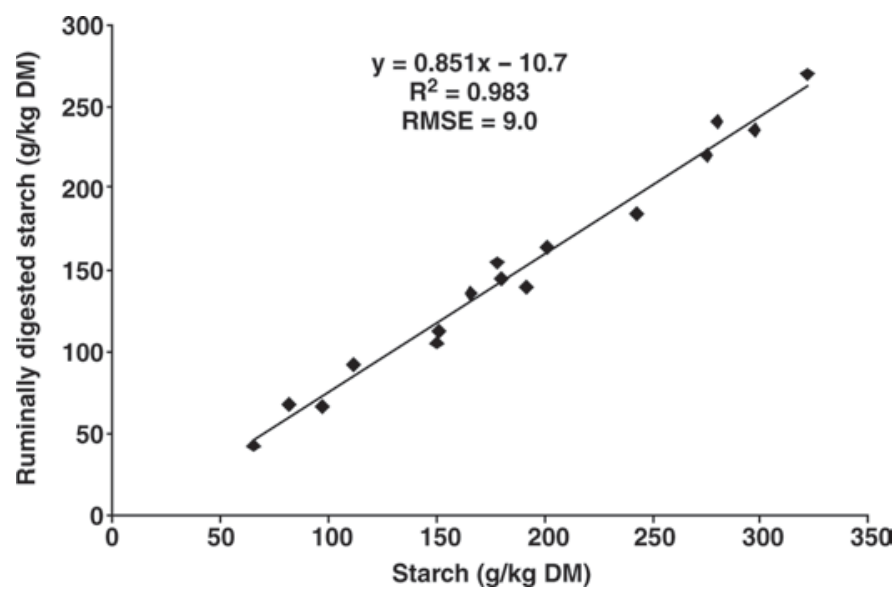

Figure 1. Relationship between dietary concentration of starch and ruminally digested starch estimated by simple regression analysis. RMSE $=$ residual mean squared error.

\section{NDF Digestion}

The regression between ruminal (rdNDF) and totaltract NDF digestion (dNDF) implied that $95 \%$ of the total NDF digestion occurred in the rumen (Figure 2). The relationship was similar when estimated using the fixed regression model:

$$
\begin{aligned}
& \operatorname{rdNDF}(\mathrm{kg} / \mathrm{d})=-0.14( \pm 0.075)+0.972( \pm 0.0173) \\
& \quad \times \operatorname{dNDF}(\mathrm{kg} / \mathrm{d}) ;\left(\mathrm{RMSE}=0.266 ; \mathrm{R}^{2}=0.964\right) . \quad[2]
\end{aligned}
$$

The parameters were similar for the fixed and mixed models. The small RMSE of the fixed regression model suggests that experimental methodologies were consistent, resulting in relatively small between-laboratory variations. The slope of model [2] decreased to 0.94 by forcing the intercept through zero. When the data from studies applying total fecal collection $(\mathrm{n}=83)$ were analyzed separately, RMSE values were reduced to 0.125 and 0.228 for the mixed and fixed models, respectively. The estimated difference between the large particle markers (iNDF vs. Cr-mordanted fiber) in $\mathrm{rdNDF}$ was small $(-0.04 \mathrm{~kg} / \mathrm{d})$ and nonsignificant $(P=0.69)$.

Ruminal NDF digestibility (NDFD) was closely related to total-tract NDF digestibility (Figure 3). The slope suggested that ruminal digestion accounted for $97.6 \%$ of total NDF digestion. The corresponding relationship estimated using a fixed regression model was

$$
\begin{gathered}
\mathrm{rNDFD}=-0.044( \pm 0.020)+1.005( \pm 0.032) \\
\mathrm{NDFD} ;\left(\mathrm{RMSE}=0.042 ; \mathrm{R}^{2}=0.891\right) .
\end{gathered}
$$




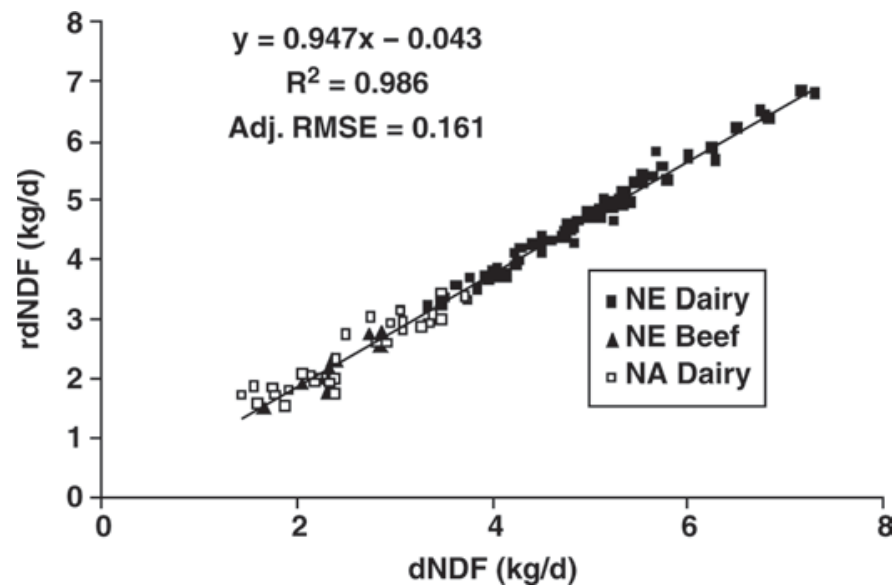

Figure 2. Relationship between the amounts of total-tract NDF digestion (dNDF) and ruminal NDF digestion (rdNDF). The data points for North European dairy and beef cattle and North American dairy cow trials are represented by different symbols. The regression equation is $\mathrm{rdNDF}=-0.04( \pm 0.108)+0.947( \pm 0.0243) \times \mathrm{dNDF}$ [residual mean squared error (RMSE) adjusted for random study effect $=0.161]$.

The intercept of the equation was significantly different from zero $(P=0.03)$. Because of this negative intercept, the slope decreased to 0.933 when the regression line was forced through zero.

The contribution of rumen to total NDF digestion increased as total NDF digestibility and dietary NDF concentration increased (Table 3). It was not influenced $(P>0.10)$ by DMI, proportion of concentrate in the diet or concentrate fat concentration.

\section{Relationship Between Omasal Nonammonia CP Flow and Milk Protein Yield}

Milk protein yield increased quadratically as a function of omasal flow of nonammonia $\mathrm{CP}$ when analyzed with a mixed model (Figure 4), but the quadratic effect was nonsignificant using a simple regression model. When the data were adjusted for the random study effect, the RMSE value decreased markedly, indicating substantial between-study differences among studies in nutrient flows, milk protein yield, or both. However,

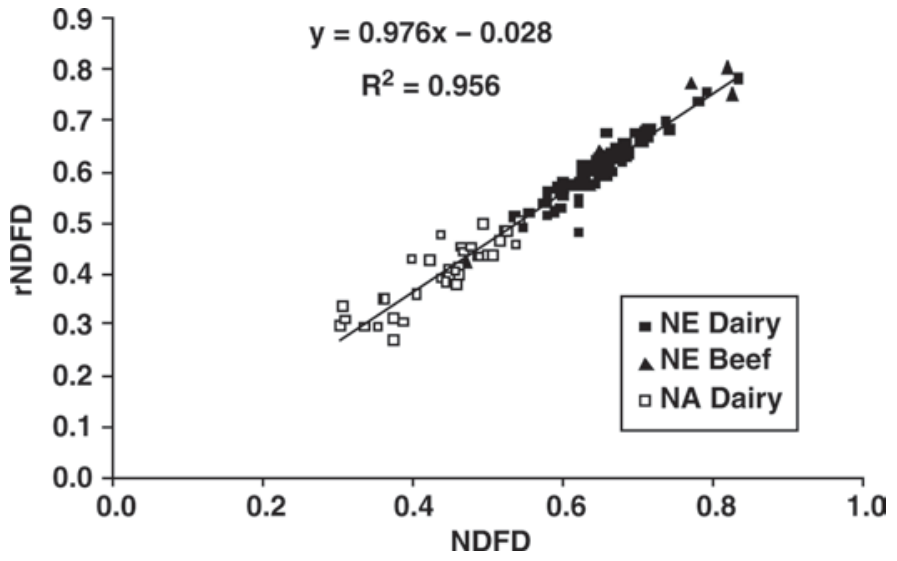

Figure 3. Relationship between the total-tract NDF digestibility (NDFD) and ruminal NDF digestibility (rNDFD). The data points for North European dairy and beef cattle and North American dairy cow trials are represented by different symbols. The regression equation is $\mathrm{rNDFD}=-0.028( \pm 0.027)+0.976( \pm 0.044) \times \mathrm{NDFD}$ [residual mean squared error (RMSE) adjusted for random study effect $=0.025]$.

the results from studies conducted in Northern Europe and North America fit on common regression lines.

\section{DISCUSSION}

\section{OM Digestion}

Some differences in omasal and duodenal flows might be expected due to VFA absorption and NDF digestion in the omasum and endogenous secretions into the abomasum. Direct comparisons between omasal and abomasal (Punia et al., 1988) and omasal and duodenal sampling (Ahvenjärvi et al., 2000) indicated a close relationship in flow estimates between the sampling sites. The correlation coefficients based on treatment mean data and individual cow data were 0.97 and 0.93 in the studies of Punia et al. (1988) and Ahvenjärvi et al. (2000), respectively. In the present study, variation observed in apparent and true ruminal OM digestibility were acceptable, with the median SD values being smaller (3.8 and 2.8 percentage units) than the corresponding 25 th percentile $(4.0$ and 3.6 percent-

Table 3. The effects of different parameters on the contribution of the rumen to total NDF digestion (\%)

\begin{tabular}{|c|c|c|c|c|c|c|c|}
\hline Item & Unit & Intercept & $\mathrm{SE}$ & Estimate & $\mathrm{SE}$ & $P$-value & $\mathrm{RMSE}^{1}$ \\
\hline $\mathrm{DMI} / \mathrm{BW}^{2}$ & $\mathrm{~g} / \mathrm{kg}$ & 99.1 & 3.94 & -0.20 & 0.124 & 0.11 & 3.95 \\
\hline Concentrate fat & $\mathrm{g} / \mathrm{kg}$ of $\mathrm{DM}$ & 93.8 & 1.23 & -0.052 & 0.0457 & 0.26 & 3.98 \\
\hline $\mathrm{CP}$ & $\mathrm{g} / \mathrm{kg}$ of $\mathrm{DM}$ & 88.0 & 4.87 & 0.031 & 0.0303 & 0.31 & 3.98 \\
\hline
\end{tabular}

${ }^{1}$ Residual mean square error; adjusted for random study effect.

${ }^{2} \mathrm{DMI}$ as a proportion of BW.

${ }^{3}$ Proportion of concentrate DMI in total DMI. 

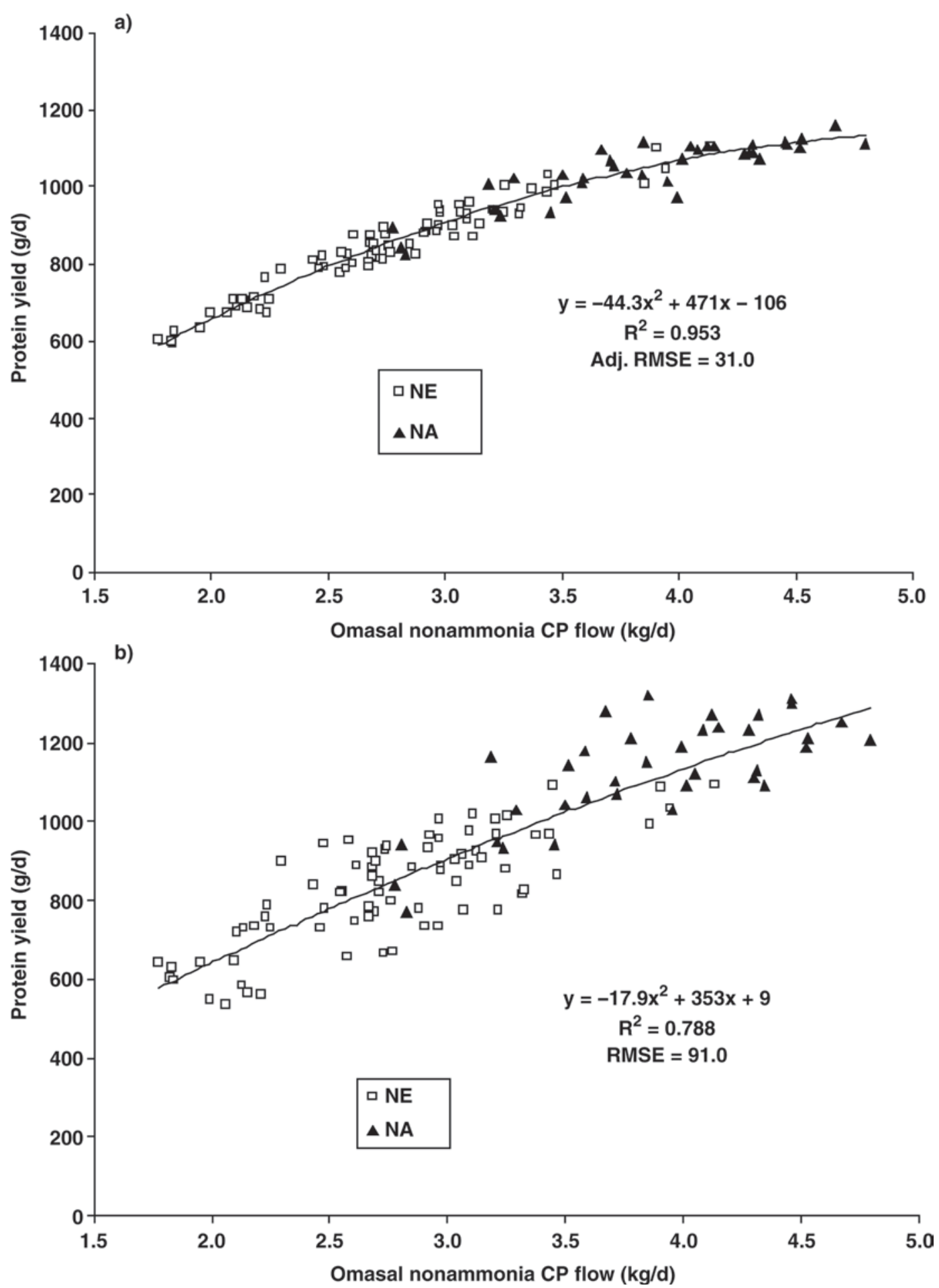

Figure 4. Relationship between omasal nonammonia CP flow and milk protein yield estimated by (a) mixed or (b) fixed regression models. $\mathrm{NE}=$ data from studies conducted in North Europe; $\mathrm{NA}=$ data from studies conducted in North America. RMSE = residual mean squared error.

age units) in duodenal sampling studies (Titgemeyer, 1997).

Results were less conclusive in the study of Ipharraguerre et al. (2007) as indicated by the low correlation coefficient (0.33) between omasal and duodenal $\mathrm{OM}$ flow. Standard errors were similar between the sampling sites in the 2 other studies (Punia et al., 1988; Ahvenjärvi et al., 2000), but were markedly greater for 
duodenal measurements in the study of Ipharraguerre et al. (2007). Large differences in duodenal OM flows calculated using $\mathrm{Cr}, \mathrm{Yb}$, or Co as markers strongly suggested that duodenal samples were not representative of true digesta flowing into the duodenum in this study. Duodenal flows of OM and starch were markedly higher when computed using $\mathrm{Yb}$ and Co as markers, resulting in negative, biologically unrealistic estimates of ruminal digestion.

Unrepresentative duodenal sampling occurs because of a tendency for digesta to separate during collection such that digesta can be considered to be 2 distinct phases (Faichney, 1975). It was suggested that unrepresentative samples could be reconstituted physically or mathematically to represent true digesta using markers that exhibit differential affinities for individual digesta phases, assuming that the assumption of 2 homogeneous phases holds true. The triple-marker method of France and Siddons (1986) that was used in all of the present studies is an extension of Faichney's (1975) double-marker technique to correct for unrepresentative digesta sampling.

As with duodenal sampling, the major shortcoming of the omasal sampling technique arises from the collection of samples that are not representative of true digesta entering the omasal canal (Huhtanen et al., 1997; Ahvenjärvi et al., 2000, 2003). Calculation of reconstitution factors using the triple-marker system indicated that omasal digesta samples comprised at least 3 distinct phases that tended to separate during sampling (Ahvenjärvi et al., 2003). Flow estimates based on single markers varied markedly as indicated by low correlation coefficients, as was also reported for duodenal sampling (Ipharraguerre et al., 2007). These data strongly support the conclusions of Faichney (1980, 1993) that when the samples are taken from a simple cannula, single marker methods result in flow estimates that can be grossly in error. If there are no errors in marker analysis, flow estimates should be the same irrespective of the marker used if the sample is representative of true digesta. Ipharraguerre et al. (2007) speculated that when particles had different functional specific gravities or when sieving could result due to the presence of large particulate matter (e.g., long fiber particles), aspiration of sample through the sampling tube could result in collection of incorrect mixtures of digesta fractions. However, comparisons of particle size distributions in omasal versus duodenal or fecal samples (Huhtanen et al., 1997; Ahvenjärvi et al., 2001) do not indicate discrimination of any particle size fraction during aspiration of the digesta sample from omasal canal. Furthermore, dividing the particle phase into small- and large-particle fractions in the triple-marker system should reduce, but not completely eliminate, errors when particulate matter is unrepresentative of total solids.

High correlation coefficients between omasal and abomasal/duodenal flow estimates in studies using double- (Punia et al., 1988) or triple-marker methods (Ahvenjärvi et al. 2000) and a weak correlation when omasal flow was estimated using the triple-marker method and duodenal flow using $\mathrm{Cr}_{2} \mathrm{O}_{3}$ as a single marker (Ipharraguerre et al., 2007) suggest that the higher precision of flow estimates based on omasal compared with duodenal sampling is more likely the result of the marker methods applied in the study rather than sampling site.

In the present data, either Cr-mordanted fiber or iNDF was used as the large particle marker. The flow estimates based on the triple-marker approach using either large-particle marker resulted in quantitatively similar flow estimates that were also highly $(\mathrm{r}=0.99)$ correlated (Ahvenjärvi et al., 2003). Both of these markers are primarily associated with large particulate matter (Ahvenjärvi et al., 2003). Indigestible NDF is an internal marker intimately associated with dietary fiber, and its fecal recovery has met the criterion of an ideal marker (Huhtanen et al., 1994; Ahvenjärvi et al., 2001). Rumen residence time of Cr-mordanted fiber was similar to that of iNDF, as estimated by the rumen evacuation method (Huhtanen and Kukkonen, $1995)$ and to ${ }^{15} \mathrm{~N}$-labeled forage ADIN (Ahvenjärvi et al., 2004), indicating that the flow characteristics of Cr-mordants are similar to that of dietary fiber. In contrast, chromic oxide is not associated with any digesta phase (Merchen, 1988), probably because of its high specific gravity, which can lead to erroneous flow estimates with unrepresentative digesta sampling.

Apparent (41\%) and true (72\%) ruminal digestibility, estimated with regressions between the amounts of OM digested and OM intake, were higher than the corresponding values based on duodenal sampling (24 and $37 \%$; Clark et al., 1992). The lower values in the data of Clark et al. (1992) are partly due to positive intercepts (i.e., positive, and biologically impossible, digestion at zero OM intake). Fixed model $\mathrm{R}^{2}$ values of regressions of ruminal $\mathrm{OM}$ digestibility on OM intake were markedly higher in our data set (0.85 vs. 0.53 for apparent and 0.96 vs. 0.56 for true OM digestion) compared with the results of Clark et al. (1992). In addition to random experimental error, unexplained variation can arise from true variation in ruminal and total-tract digestibility. However, it is not likely that the lower variability in our data can be attributed to more uniform digestibility, because our data included results obtained over a wide range of diets from both typical North American (corn silage + corn grain) and Northern European (grass silage + barley grain) trials. 
Variable estimates of starch digestibility resulting from unrepresentative proportions of undigested grain particles in duodenal digesta (Titgemeyer, 1997) may explain the greater variability in estimates of ruminal OM digestibility that results with duodenal data (Clark et al., 1992). When a disproportionate number of grain particles are collected, sample starch content will be enriched and ruminal starch digestion will be underestimated (Titgemeyer, 1997). In the present study, ruminal starch digestion did not display large random variation (Figure 3), which may be partly because barley and oats were the main starch sources in the diet in these studies. True ruminal starch digestibility with barley-based diets (85\%) compares well with the mean of $87 \%$ (12 diets) reported in the review of Nocek and Tamminga (1991) and does not indicate discrimination of grain particles during the aspiration of omasal samples. However, more studies are needed to evaluate the omasal sampling technique for estimating ruminal starch digestibility with corn-based diets. Starch concentration in duodenal digesta samples (Ipharraguerre et al., 2007) and ruminal starch digestibility (Voelker and Allen, 2003) exhibit large variation in studies using a simple T-piece cannula and $\mathrm{Cr}_{2} \mathrm{O}_{3}$ as flow marker, even when the diets contained the same starch sources. Using the double-marker method may not solve the problems related to unrepresentative digesta sampling because most particulate markers are not intimately associated with particles rich in starch (Huhtanen and Sveinbjörnsson, 2006). However, despite the problems in determination of starch flow, the double- or triplemarker techniques are likely to improve the accuracy of the flow measurements of other dietary components even with diets containing large grain particles.

\section{NDF Digestion}

Because most of the cell wall digestion in cattle takes place in the rumen (Van Soest, 1994; Huhtanen et al., 2006), comparisons between omasal and fecal NDF flows or ruminal and total NDF digestibility can be used as an indirect measure of both of the accuracy and precision of flow measurements and marker function.

Relatively small residuals from regressions of ruminal NDF digestion/digestibility on total NDF digestion/ digestibility, and of ruminal $\mathrm{OM}$ digestion on $\mathrm{OM}$ intake, may be interpreted as indicating that there were only small random errors in digesta flow measurements. Compared with 10 duodenal flow studies in dairy cows that were published in the Journal of Dairy Science (Christensen et al., 1996; Oba and Allen, 2000; Callison et al., 2001; Ipharraguerre et al., 2002; Harvatine et al., 2002; Oba and Allen, 2003; Voelker and Allen, 2003; Ipharraguerre and Clark, 2005; Taylor and Allen,
2005; Harvatine and Allen, 2006), the residual standard deviation of ruminal NDF digestibility was lower in our data set (4.3 vs. $8.9 \%$ ). Smaller variability in our data is likely related to the use of the triple-marker technique (France and Siddons, 1986) in estimating digesta flow compared with using $\mathrm{Cr}_{2} \mathrm{O}_{3}$ as a single marker in duodenal sampling studies. High (0.93-0.96) correlation coefficients between omasal and duodenal NDF and ADF flow estimates (Ahvenjärvi et al., 2000) also suggest that the precision of flow estimates could be more closely related to marker methods rather than to sampling site, provided that multiple marker techniques are used. Lower $(0.36-0.85)$ correlation coefficients between omasal NDF flow estimates based on different single markers support this suggestion (Ahvenjärvi et al., 2003).

A more heterogeneous distribution of Cr-mordanted particles in omasal and fecal particles than iNDF could, in the case of unrepresentative sampling, result in erroneous flow estimates (Ahvenjärvi et al., 2001). However, in the present study, the choice of large-particle marker did not influence ruminal NDF digestibility estimates, which agrees with previous results from a direct comparison of triple-marker systems using $\mathrm{Cr}$ mordanted fiber or iNDF as a large particle marker (Ahvenjärvi et al., 2003). However, Cr-mordanted fiber cannot be recommended as a large-particle marker in studies investigating ruminal lipid metabolism, because CoEDTA must be replaced with CrEDTA in the triplemarker system to avoid the effects of cobalt on milk fatty acid composition (Shingfield et al., 2008).

In the present data set, NDF digestion occurred largely in the rumen and the contribution of the hindgut to total-tract NDF digestion was low. Our values, based either on proportion of rumen digestion of total NDF digestion or on regression approaches, are consistent with the duodenal data reported by Tamminga (1993) and fall within expected ranges suggested by Titgemeyer (1997). In contrast, the data (26 dairy cow diets) compiled by Firkins (1997) indicated that only $66 \%$ of total NDF digestion occurred in the rumen. The relationship between ruminal and total NDF digestibility in the data set of Firkins (1997) was much weaker $\left(\mathrm{R}^{2}\right.$ $=0.24)$ than in our data set $\left(\mathrm{R}^{2}=0.89\right)$. A greater proportion of nonforage fiber in those diets could have contributed to the lower proportion of ruminal NDF digestion. However, similar (e.g., Harvatine and Allen, 2006; Ipharraguerre et al., 2002) or even much lower (Oba and Allen, 2003) proportions of ruminal digestion of total NDF digestion compared with the data set of Firkins (1997) have been reported in dairy cows.

The contribution of the hindgut to total NDF digestion should be somewhat lower with duodenal compared with omasal sampling because of additional fiber diges- 
tion occurring in the omasum. Smith (1984) calculated that $10 \%$ of the potentially digestible fiber entering the omasum could be digested. This value was based on an estimated 5-h omasal turnover time. Ahvenjärvi et al. (2001) determined, based on iNDF to NDF ratio in fractions of different particle size separated by wet-sieving, that the proportion of NDF digestion in the omasum was $7 \%$ of the total and was greater than the proportion occurring in the intestines $(3 \%)$. These results are consistent with simultaneous measurements of omasal and duodenal NDF flow in dairy cows (Ahvenjärvi et al., 2000). Using iNDF to NDF ratio in duodenal digesta and feces, Huhtanen et al. (1994) estimated that 10 to $16 \%$ of the NDF entering the duodenum was digested in the intestines, which corresponded to between 3 and $5 \%$ of total-tract NDF digestion. Using a combined rumen in situ and intestinal mobile bag technique, Varvikko and Vanhatalo (1992) estimated that $90 \%$ of total NDF digestion occurred in the reticulo-rumen. This value is probably an underestimate, because the rumen incubation period was only $16 \mathrm{~h}$. Huhtanen and Vanhatalo (1997) used a compartmental modeling approach for combined ruminal in situ and intestinal mobile bag data to estimate ruminal and total-tract NDF digestibility. Predicted ruminal contribution to total NDF digestion was, on average, $95 \%$ for 5 grasses harvested at different stages of maturity. The disappearance of NDF from mobile bags in the intestines corresponded to an average 5 -h retention time assuming similar rates of digestion in the rumen and hindgut. It is noteworthy that the contribution of intestines to the total NDF disappearance remained below $20 \%$ even when the rumen incubation period was as short as $12 \mathrm{~h}$.

The small contribution of the postruminal compartments to NDF digestion is consistent with the short retention time of feed particles in these compartments. Both slaughter studies using lignin or iNDF ratios for estimating compartmental pool sizes (Paloheimo and Mäkelä, 1959; S. Ahvenjärvi; unpublished data) and marker techniques (Ellis et al. 2002) have demonstrated that the residence time of feed particles in the hindgut is only about $10 \%$ of the total residence time in the digestive tract. Suboptimal conditions in the rumen for fiberdigesting bacteria (e.g., high dietary concentrations of NFC and unsaturated fatty acids) can shift NDF digestion to the lower digestive tract. In the present study, these factors had only minor and nonsignificant effects on the proportion of total NDF digestion occurring in the rumen. Moreover, the predicted contribution of the hindgut increased only from 4 to 10 percentage units when the rate of ruminal NDF digestion decreased from 7.5 to $4 \% / \mathrm{h}$, but remained unchanged in the hindgut (7.5\%/h; Huhtanen et al., 2006). In this model, residence times in different segments of the digestive tract were based on slaughter data. Lower viable bacterial counts (Ulyatt et al., 1975) and particle-associated enzyme activities (Michalet-Doreau et al., 2002) do not suggest a faster rate of NDF digestion in the hindgut compared with the rumen. Use of fecal inoculum has, in most cases, resulted in reduced in vitro digestibility as well as a lower extent and rate of gas production (for review, see Mould et al., 2005), observations highlighting the limited potential of the hind-gut to compensate for reduced ruminal NDF digestion.

The estimates of the contribution of the rumen to the total NDF digestion that were based on omasal sampling technique are consistent with estimates derived using other experimental techniques and modeling approaches, which suggests that the measurements of omasal flow are reliable. Smaller residual standard deviations for ruminal NDF digestibility, compared with typical values from studies using duodenal sampling with a single marker method, indicate that omasal flow estimates are also inherently precise. Experimental evidence based on changes in internal marker ratios, combined with results obtained using in situ and mobile bags, relative residence times in difference segments of digestive tract, and relative microbial activity in the rumen and hindgut, does not support a large compensatory role of hindgut in NDF digestion. Values of 30 to $40 \%$ for the contribution of hindgut to total NDF digestion may rather reflect technical problems related to the collection of unrepresentative digesta samples and the use of a single marker $\left(\mathrm{Cr}_{2} \mathrm{O}_{3}\right)$ that is not associated with any digesta phase.

\section{Protein Flow Versus Milk Protein Yield}

Because milk protein yield has no associated flow marker errors and it can be quantified reliably, the close relationship between omasal nonammonia CP flow and milk protein yield (Figure 4) can be interpreted as further evidence of the credence of omasal flow data in the present study. The adjusted RMSE of the quadratic model predicting milk protein yield from nonammonia CP flow $(31 \mathrm{~g} / \mathrm{d})$ is acceptable compared with the corresponding values obtained with models based on parameters not including errors of flow measurements. In a recent meta-analysis (Huhtanen and Hristov, 2009), the adjusted RMSE of milk protein with the corresponding quadratic MP (NRC, 2001) was 23 (Northern European data; $\mathrm{n}=998$ diets) and $40 \mathrm{~g} / \mathrm{d}$ (North American data; $\mathrm{n}=739$ ). Although energy (total digestible nutrients) intake was the major factor contributing to milk protein yield (Huhtanen and Hristov, 2009), an accurate prediction of milk protein yield from omasal NAN flow data suggests small random variation of NAN flow estimates. A slightly larger adjusted RMSE of milk protein yield 
(47) was reported by Firkins et al. (2006) for a model based on DMI and dietary concentrations of RDP and RUP. In flow studies, the protein yield variance could be expected to be larger than in production trials because of intensive sampling procedures. It is noteworthy that the data from North America with Holstein cows and from Northern Europe studies with Ayrshire cows fed completely different diets fit a common regression line (Figure 4), confirming the consistency of experimental methodologies. Larger RMSE with fixed model regression analysis reflects partly the study effect in flow measurements, but the influences of variation in DIM, environmental factors and other diet characteristics on protein yield cannot be ruled out. For example, low concentrations of essential or limiting AA in high RUP feeds such as corn gluten meal and cottonseed meal (Korhonen et al., 2002; Brito et al., 2007) may impair the relationship between protein flow and milk protein yield. However, the $\mathrm{R}^{2}$ value (0.79) from the simple quadratic regression model (effect of study not considered) predicting milk protein yield from omasal nonammonia $\mathrm{CP}$ flow was markedly higher than that (0.51) estimated from the NRC (2001) data set with a model using DMI and concentrations of RDP and RUP as independent variables.

\section{CONCLUSIONS}

A limited number of direct comparisons between omasal versus abomasal/duodenal digesta in studies using double- or triple marker methods indicate that duodenal sampling can be replaced successfully with omasal sampling. Indirect validations based on the relationships between ruminal and total NDF digestion and digestibility, OM intake and apparent or true ruminal OM digestion, and between omasal nonammonia $\mathrm{CP}$ flow and milk protein yield provide further evidence that omasal measurements are accurate. Small prediction errors of the models indicate the high precision of these data. However, the greater precision of nutrient flows based on omasal sampling compared with published duodenal sampling data are more likely due to the marker technique used rather than sampling site per se.

\section{ACKNOWLEDGMENTS}

The authors thank Andre Brito, Agriculture and Agri-Food Canada, Dairy and Swine Research and Development Centre, Sherbrooke, Québec, Canada; Mark McGee, Grange Beef Research Unit, Teagasc, County Meath, Ireland; Marketta Rinne, MTT Agrifood Research Finland, Jokioinen, Finland; Auvo Sairanen, MTT Agrifood Research Finland, Maaninka, Finland; and Aila Vanhatalo, University of Helsinki, Helsinki,
Finland for providing complementary data. Experiments within the European portion of the database were supported from funding received from the European Union (Project QLK1-2002-02362; Production of CLAenriched products by natural means and LIPGENE, an EU Sixth Integrated Project; 2004-2009; http://www. lipgene.tcd.ie) and the Finnish Ministry of Agriculture and Forestry.

\section{REFERENCES}

Ahvenjärvi, S., B. Skiba, and P. Huhtanen. 2001. Effect of heterogeneous digesta chemical composition on the accuracy of measurements of fiber flow in dairy cows. J. Anim. Sci. 79:1611-1620.

Ahvenjärvi, S., A. Vanhatalo, A. N. Hristov, and P. Huhtanen. 2004. Passage kinetics of internal and external markers in lactating dairy cows. J. Anim. Feed Sci. 13(Suppl. 1):19-22.

Ahvenjärvi, S., A. Vanhatalo, P. Huhtanen, and T. Varvikko. 2000. Determination of forestomach digestion in lactating dairy cows by omasal or duodenal sampling. Br. J. Nutr. 83:67-77.

Ahvenjärvi, S., A. Vanhatalo, K. J. Shingfield, and P. Huhtanen. 2003. Determination of digesta flow entering the omasal canal of dairy cows using different marker systems. Br. J. Nutr. 90:41-52.

Brito, A. F., G. A. Broderick, and S. M. Reynal. 2007. Effects of different protein supplements on omasal nutrient flow and microbial protein synthesis in lactating dairy cows. J. Dairy Sci. 90:1828-1841.

Broderick, G. A., P. Huhtanen, S. Ahvenjärvi, S. M. Reynal, and K. J. Shingfield. 2010. Quantifying ruminal nitrogen metabolism using the omasal sampling technique in cattle-A meta-analysis. J. Dairy Sci. 93:3216-3230.

Callison, S. L., J. L. Firkins, M. L. Eastridge, and B. L. Hull. 2001. Site of nutrient digestion by dairy cows fed corn of different particle sizes or steam-rolled. J. Dairy Sci. 84:1458-1467.

Christensen, R. A., T. R. Overton, J. H. Clark, J. K. Drackley, D, R. Nelson, and S. A. Blum. 1996. Effects of dietary fat with or without nicotinic acid on nutrient flow to the duodenum of dairy cows. J. Dairy Sci. 79:1410-1424.

Clark, J. H., T. H. Klusmeyer, and M. R. Cameron. 1992. Symposium: Nitrogen metabolism and amino acid nutrition in dairy cattle: Microbial protein synthesis and flows of nitrogen fractions to the duodenum of dairy cows. J. Dairy Sci. 75:2304-2323.

Ellis, W. C., M. J. Wylie, and J. H. Matis. 2002. Validity of specifically applied rare earth elements and compartmental models for estimating flux of undigested plant tissue residues through the gastrointestinal tract of ruminants. J. Anim. Sci. 80:2753-2758.

Faichney, G. J. 1975. The use of markers to partition digestion within the gastrointestinal tract of ruminants. Page 277 in Digestion and Metabolism in the Ruminant. I. W. McDonald, and A. C. I. Warner, ed. The University of New England Publishing Unit, Sydney, Australia.

Faichney, G. J. 1980. The use of markers to measure digesta flow from the stomach of sheep fed once daily. J. Agric. Sci. (Camb.) 94:313-318.

Faichney, G. J. 1993. Digesta flow. Pages 53-85 in Quantitative Aspects of Ruminant Digestion and Metabolism. J. M. Forbes and J. France, ed. CAB Int., Wallingford, UK.

Firkins, J. L. 1997. Effects of feeding nonforage fiber sources on site of fiber digestion. J. Dairy Sci. 80:1426-1437.

Firkins, J. L., A. N. Hristov, M. B. Hall, G. A. Varga, and N. R. StPierre. 2006. Integration of ruminal metabolism in dairy cattle. J. Dairy Sci. 89(E Suppl.):E31-E51.

France, J., and R. C. Siddons. 1986. Determination of digesta flow by continuous marker infusion. J. Theor. Biol. 121:105-119.

Harmon, D. L., and C. J. Richards. 1997. Considerations for gastrointestinal cannulation in ruminants. J. Anim. Sci. 75:22482255 .

Harvatine, D. I., J. E. Winkler, M. Devant-Guille, J. L. Firkins, N. R. St-Pierre, B. S. Oldick, and M. L. Eastridge. 2002. Whole linted 
cottonseed as a forage substitute: Fiber effectiveness and digestion kinetics. J. Dairy Sci. 85:1988-1999.

Harvatine, K. J., and M. S. Allen. 2006. Effects of fatty acid supplements on ruminal and total tract nutrient digestion in lactating dairy cows. J. Dairy Sci. 89:1092-1103.

Hristov, A. N. 2007. Comparative characterization of reticular and duodenal digesta and possibilities of estimating microbial outflow from the rumen based on reticular sampling in dairy cows. J. Anim. Sci. 85:2606-2613.

Hristov, A. N., and G. Broderick. 1996. Synthesis of microbial protein in ruminally cannulated cows fed alfalfa silage, alfalfa hay or corn silage. J. Dairy Sci. 79:1627-1637.

Huhtanen, P., S. Ahvenjärvi, M. R. Weisbjerg, and P. Nørgaard. 2006. Digestion and passage of fiber in ruminants. Pages 87-135 in Ruminant Physiology. K. Sejrsen, T. Hvelplund, and M. O. Nielsen, ed. Wageningen Acad. Publ., Wageningen, the Netherlands.

Huhtanen, P., P. G. Brotz, and L. D. Satter. 1997. Omasal sampling technique for assessing fermentative digestion in the forestomach of dairy cows. J. Anim. Sci. 75:1380-1392.

Huhtanen, P., and A. N. Hristov. 2009. A meta-analysis of the effects of protein concentration and degradability on milk protein yield and milk N efficiency in dairy cows. J. Dairy Sci. 92:3222-3232.

Huhtanen, P., K. Kaustell, and S. Jaakkola. 1994. The use of internal markers to predict total digestibility and duodenal flow of nutrients in cattle given six different diets. Anim. Feed Sci. Technol. 48:211-227.

Huhtanen, P., and U. Kukkonen. 1995. Comparison of methods, markers and sampling sites for estimating digesta passage kinetics in cattle fed at two levels of intake. Anim. Feed Sci. Technol. $52: 141-158$.

Huhtanen, P., and S. Sveinbjörnsson. 2006. Evaluation of methods for estimating starch digestibility and digestion kinetics. Anim. Feed Sci. Technol. 130:95-113.

Huhtanen, P., and A. Vanhatalo. 1997. Ruminal and total plant cell wall digestibility estimated by a combined in situ method utilizing mathematical model. Br. J. Nutr. 78:583-598.

Ipharraguerre, I. R., and J. H. Clark. 2005. Varying protein and starch in the diet of dairy cows. II. Effects on performance and nitrogen utilization for milk production. J. Dairy Sci. 88:2556-2570.

Ipharraguerre, I. R., S. M. Reynal, M. Lineiro, G. A. Broderick, and J. H. Clark. 2007. A comparison of sampling sites, digesta and microbial markers, and microbial references for assessing the postruminal supply of nutrients in dairy cows. J. Dairy Sci. 90:1904-1919.

Ipharraguerre, I. R., Z. Shabi, J. H. Clark, and D. E. Freeman. 2002 Ruminal fermentation and nutrient digestion by dairy cows fed varying amounts of soyhulls as a replacement for corn grain. J. Dairy Sci. 85:2890-2904.

Korhonen, M., A. Vanhatalo, and P. Huhtanen. 2002. Effect of protein source on amino acid supply, milk production, and metabolism of plasma nutrients in dairy cows fed grass silage. J. Dairy Sci. 85:3336-3351.

Merchen, N. R. 1988. Digestion, absorption and excretion in ruminants. Pages 172-201 in The Ruminant Animal Digestive Physiology and Nutrition. D. C. Church, ed. Prentice-Hall, Englewood Cliffs, NJ.

Michalet-Doreau, B., I. Fernandez, and G. Fonty. 2002. A comparison of enzymatic and molecular approaches to characterize the cellulolytic microbial ecosystems of the rumen and the caecum. J. Anim. Sci. 80:790-796.

Mould, F. L., K. E. Kleim, R. Morgan, and R. M. Mauricio. 2005. In vitro microbial inoculum: A review of its function and properties. Anim. Feed Sci. Technol. 123-124:31-50.

MTT. 2006. Rehutaulukot ja ruokintasuositukset (Feed tables and feeding recommendations, in Finnish). http://www.mtt.fi/ rehutaulukot Accessed Feb. 1, 2008.

Nocek, J. E., and S. Tamminga. 1991. Site of digestion of starch digestion in the gastrointestinal tract of dairy cows and its effect on milk yield and composition. J. Dairy Sci. 74:3598-3629.

Nousiainen, J., M. Rinne, and P. Huhtanen. 2009. A meta-analysis of feed digestion in dairy cows. 1 . The effects of forage and concentrate factors on total diet digestibility. J. Dairy Sci. 92:5019-5030.
NRC. 2001. Nutrient Requirements of Dairy Cattle. 7th rev. ed. National Academy Press, Washington, DC

Oba, M., and M. S. Allen. 2000. Effects of brown midrib 3 mutation in corn silage on productivity of dairy cows fed two concentrations of dietary neutral detergent fiber: 3. Digestibility and microbial efficiency. J. Dairy Sci. 83:1350-1358.

Oba, M., and M. S. Allen. 2003. Effects of corn grain conservation method on ruminal digestion kinetics for lactating dairy cows at two dietary starch concentrations. J. Dairy Sci. 86:184-194.

Paloheimo, L., and A. Mäkelä. 1959. Further studies on the retention time of food in the digestive tract of cows. Acta Agric. Fenn. 94:15-39.

Punia, B. S., J. Leibholz, and G. J. Faichney. 1988. Effects of level of intake and urea supplementation of alkali-treated straw on protozoal and bacterial nitrogen synthesis in the rumen and partition of digestion in cattle. Aust. J. Agric. Res. 39:1181-1194.

Reynal, S. M., and G. A. Broderick. 2003. Effects of feeding dairy cows protein supplements of varying ruminal degradability. J. Dairy Sci. $86: 835-843$.

Rinne, M., A. Olt, J. Nousiainen, A. Seppälä, M. Tuori, C. Paul, M. D. Fraser, and P. Huhtanen. 2006. Prediction of legume silage digestibility from various laboratory methods. Grass Forage Sci. $61: 354-362$.

SAS Institute. 1999. SAS User's Guide: Statistics. Version 8.2. SAS Inst. Inc., Cary, NC.

Shingfield, K. J., A. Ärölä, S. Ahvenjärvi, A. Vanhatalo, V. Toivonen, J. M. Griinari, and P. Huhtanen. 2008. Ruminal infusions of cobaltethylenediamine-tetraacetic acid reduce mammary 89 -desaturase index and alter milk fatty acid composition in lactating cows. J. Nutr. 138:710-717.

Smith, R. H. 1984. Microbial activity in the omasum. Proc. Nutr. Soc. $43: 63-68$.

St-Pierre, N. R. 2001. Invited Review: Integrating quantitative findings from multiple studies using mixed model methodology. J. Dairy Sci. $84: 741-755$

Tamminga, S. 1993. Influence of feeding management on ruminant fiber digestibility. Pages 571-602 in Forage Cell Wall Structure and Digestibility. H. G. Jung, D. R. Buxton, R. D. Hatfield, and J. Ralph, ed. American Society of Agronomy, Madison, WI.

Taylor, C. C., and M. S. Allen. 2005. Corn grain endosperm type and brown midrib 3 corn silage: Site of digestion and ruminal digestion kinetics in lactating cows. J. Dairy Sci. 88:1413-1424.

Titgemeyer, E. C. 1997. Design and interpretation of nutrient digestion studies. J. Anim. Sci. 75:2235-2247.

Udén, P., P. E. Colucci, and P. J. Van Soest. 1980. Investigation of chromium, cerium and cobalt as markers in digesta. J. Sci. Food Agric. 31:625-632.

Ulyatt, M. J., O. W. Dellow, C. S. Reid, and T. Bauchop. 1975. Structure and function of the large intestine in ruminants. Page 119 in Digestion and Metabolism in the Ruminant. I. W. McDonald, and A. C. I. Warner, ed. The University of New England Publishing Unit, Sydney, Australia.

Van Soest, P. J. 1994. Nutritional Ecology of the Ruminant. 2nd ed. Cornell Univ. Press, Ithaca, NY.

Varvikko, T., and A. Vanhatalo. 1992. Effect of supplementary energy and protein feeding on the true digestion of organic matter, cell walls and nitrogen by the combined-synthetic-fiber bag method. Can. J. Anim. Sci. 72:671-678.

Voelker, J. A., and M. S. Allen. 2003. Pelleted beet pulp substituted for high-moisture corn: 2. Effects on digestion and ruminal digestion kinetics in lactating dairy cows. J. Dairy Sci. 86:3553-3561.

\section{APPENDIX}

\section{List of Publications Describing the Experiments Used in the Data Analysis}

Ahvenjärvi, S., E. Joki-Tokola, A. Vanhatalo, S. Jaakkola, and P. Huhtanen. 2006. Effects of replacing grass silage with barley silage in dairy cow diets. J. Dairy Sci. 89:1678-1687. 
Ahvenjärvi, S., A. Vanhatalo, and P. Huhtanen. 2002. Supplementing barley or rapeseed meal to dairy cows fed grass-red clover silage: I. Rumen degradability and microbial flow. J. Anim. Sci. 80:21762187.

Ahvenjärvi, S, A. Vanhatalo, P. Huhtanen, and T. Varvikko. 1999. Effects of supplementation of a grass silage and barley diet with urea, rapeseed meal and heat-moisture treated rapeseed cake on omasal digesta flow and milk production in lactating dairy cows. Acta Agric. Scand., Sect. A Anim. Sci. 49:179-189.

Ahvenjärvi, S., A. Vanhatalo, P. Huhtanen, and T. Varvikko. 2000. Determination of reticulo-rumen and whole-stomach digestion in lactating cows by omasal canal or duodenal sampling. Br. J. Nutr. 83:67-77.

Ahvenjärvi, S., A. Vanhatalo, and S. Jaakkola. 2005. Herneen ruokinnallinen arvo märehtijällä [Nutritional value of field pea in dairy cow diets]. In: Herneen murskesäilöntä ja käyttö märehtijöiden ruokinnassa. Loppuraportti. [Use of ensiled pea in dairy cow diets. Final report.] MTT Agrifood Research Finland.

Arölä, A., K. J. Shingfield, A. Vanhatalo, V. Toivonen, P. Huhtanen, and J. M. Griinari. 2002. Biohydrogenation shift and milk fat depression in lactating dairy cows fed increasing levels of fish oil. J. Dairy Sci. 85(Suppl. 1):143.

Brito, A., and G. A. Broderick. 2006. Effect of varying ratios of alfalfa to corn silage on production and nitrogen utilization in dairy cows. J. Dairy Sci. 89:3924-3938.

Brito, A., G. A. Broderick, and S. M. Reynal. 2006. Effect of varying ratios of alfalfa to corn silage on omasal flow and microbial protein synthesis in dairy cows. J. Dairy Sci. 89:3939-3953.

Brito, A., G. A. Broderick, J. J. Olmos Colmenero, and S. M. Reynal. 2007. Effects of feeding formate-treated alfalfa silage or red-clover silage on omasal nutrient flow and microbial protein synthesis in lactating dairy cows. J. Dairy Sci. 90:1392-1404.

Brito, A., G. A. Broderick, and S. M. Reynal. 2007. Effects of different protein supplements on omasal nutrient flow and microbial protein synthesis in lactating dairy cows. J. Dairy Sci. 90: 1828-1841.

Brito, A. F., G. E. Trembley, H. Lapierre, A. Bertrand, Y. Castonguay, C. Bélanger, R. Benchaar, D. R. Quellet, and R. Berthiaume. 2009. Alfalfa cut at sundown and harvested as balage increase bacterial protein synthesis in late lactation dairy cows. J. Dairy Sci. 92:1092-1107.

Broderick, G. A., N. D. Luchini, S. M. Reynal, G. A. Varga, and V. A. Ishler. 2008. Effect on production of replacing dietary starch with sucrose in lactating dairy cows. J. Dairy Sci. 91:4801-4810.

Broderick, G. A., and S. M. Reynal. 2009. Effects of source of rumendegraded protein on production and ruminal metabolism in lactating dairy cows. J. Dairy Sci. 92:2822-2834.

Halmimies, A., P. Kairenius, S. Ahvenjärvi, A. Vanhatalo, V. Toivonen, D.I. Givens, R.J. Wallace, and K.J. Shingfield. Effect of forage conservation method on ruminal lipid metabolism and the rumen bacterial community in lactating cows. Unpublished.

Kairenius, P., V. Toivonen, S. Ahvenjärvi, A. Vanhatalo, P. Huhtanen, and K. J. Shingfield. 2007. Effect of fish oil alone or in combination with sunflower or linseed oil on rumen lipid metabolism and milk fat conjugated linoleic acid content in lactating cows. Page 67 in Proceedings of the II International Congress on Conjugated Linoleic Acid (CLA): From Experimental Models to Human Application, Tanka Village Resort, Villasimius (CA), Italy.

Korhonen, M., S. Ahvenjärvi, A. Vanhatalo, and P. Huhtanen. 2002. Supplementing barley or rapeseed meal to dairy cows fed grass-red clover silage: II. Amino acid profile of microbial fractions. J. Anim. Sci. 80:2188-2196.

Korhonen, M., A. Vanhatalo, and P. Huhtanen. 2002. Effect of protein source on amino acid supply, milk production, and metabolism of plasma nutrients in dairy cows fed grass silage. J. Dairy Sci. 85:3336-3351.

Korhonen, M. 2003. Amino acid supply and metabolism in relation to lactational performance of dairy cows fed grass silage based diets. PhD dissertation. Department of Animal Science Publications 68. University of Helsinki, Finland.

Kuoppala, K., S. Ahvenjärvi, M. Rinne, and A. Vanhatalo. 2009. Effects of feeding grass or red clover cut at 2 maturity stages in dairy cows. 2. Dry matter intake and cell wall digestion kinetics. J. Dairy Sci. 92:5634-5644.

Olmos Colmenero, J. J., and G. A. Broderick. 2006. Effect of dietary crude protein concentration on ruminal nitrogen metabolism in dairy cows. J. Dairy Sci. 89:1694-1703.

Owens, D., M. McGee., and T. Boland. 2008. Effect of grass regrowth interval on intake, rumen digestion and nutrient flow to the omasum in beef cattle. Anim. Feed Sci. Technol. 146:21-41.

Owens, D., M. McGee., T. Boland, and P. O'Kiely. 2008. Intake, rumen fermentation and nutrient flow to the omasum of beef cattle fed grass silage fortified with sucrose and/or supplemented with concentrate. Anim. Feed Sci. Technol. 144:23-43.

Owens, D., M. McGee., T. Boland, and P. O'Kiely. 2009. Rumen fermentation, microbial protein synthesis, and nutrient flow to the omasum in cattle offered corn silage, grass silage, or whole-crop wheat. J. Anim. Sci. 87:658-668.

Reynal, S. M., and G. A. Broderick, 2003. Effects of feeding dairy cows protein supplements of varying ruminal degradability. J. Dairy Sci. $86: 835-843$.

Reynal, S. M., and G. A. Broderick, 2005. Effect of dietary level or rumen-degraded protein on production and nitrogen metabolism in lactating dairy cows. J. Dairy Sci. 88:4045-4064.

Reynal, S. M., G. A. Broderick, S. Ahvenjärvi, and P. Huhtanen. 2003. Effect of feeding protein supplements of differing degradability on omasal flow of microbial and undegraded protein. J. Dairy Sci. 86:1292-1305.

Rinne, M., K. Kuoppala, S. Ahvenjärvi, and A. Vanhatalo. 2006. Rypsi soijaa parempi valkuaistäydennys puna-apilasäilörehua syötettäessä [Rapeseed expeller a better protein supplement than soybean expeller for dairy cows fed red clover silage]. Suomen Maataloustieteellisen Seuran julkaisuja no 21. Ed. Anneli Hopponen. Published 9 Jan. 2006. Available at http://www.smts. fi/esit06/1002.pdf.

Sairanen, A., H. Khalili, J. I. Nousiainen, S. Ahvenjärvi, and P. Huhtanen. 2005. The effect of concentrate supplementation on nutrient flow to the omasum in dairy cows receiving freshly cut grass. J. Dairy Sci. 88:1443-1453.

Shingfield, K., S. Ahvenjärvi, V. Toivonen, A. Ärölä, K. V. V. Nurmela, P. Huhtanen, and J. M. Griinari. 2003. Effect of dietary fish oil on biohydrogenation of fatty acids and milk fatty acid content in cows. Anim. Sci 77:165-179.

Shingfield, K. J., S. Ahvenjärvi, V. Toivonen, A. Vanhatalo, P. Huhtanen, and J. M. Griinari. 2008. Effect of incremental levels of sunflower oil in the diet on ruminal lipid metabolism in lactating cows. Br. J. Nutr. 99:971-983.

Shingfield, K. J., P. Kairenius, S. Ahvenjärvi, K. V. V. Nurmela, V. Toivonen, and M. J. Griinari. Effect of plant oils on ruminal lipid metabolism in lactating cows fed grass silage based diets. Unpublished.

Shingfield, K. J., P. Kairenius, S. Ahvenjärvi, V. Toivonen, and P. Huhtanen. Effect of forage to concentrate ratio on ruminal lipid metabolism and milk fatty acid composition in lactating cows fed grass silage based diets containing linseed oil. Unpublished.

Shingfield, K. J., P. Kairenius, S. Ahvenjärvi, V. Toivonen, D. I Givens, and R. J. Wallace. Effect of rapeseed lipid on ruminal lipid metabolism, rumen bacterial community, and milk fatty acid composition in lactating cows fed grass silage based diets. Unpublished.

Shingfield, K. J., P. Kairenius, S. Ahvenjärvi, A. Vanhatalo, P. Huhtanen, D. I. Givens, and V. Toivonen. Effect of level and type of concentrate on ruminal lipid metabolism and milk fatty acid composition in lactating cows fed grass silage based diets. Unpublished.

Tuori, M., M. Rinne, A. Vanhatalo, and P. Huhtanen. 2006. Omasal sampling technique in estimation of the site and extent of mineral absorption in dairy cows fed rapeseed and soybean expellers. Agric. Food Sci. Food Sci. 3:200-218

Vanhatalo, A., Kuoppala, K., S. Ahvenjärvi, and M. Rinne. 2009. Effects of feeding grass or red clover cut at 2 maturity stages in Dairy cows. 2. Nitrogen metabolism and supply of amino acids. J. Dairy Sci. 92:5620-5633. 